\title{
INOVASI MODEL SOSIALISASI \\ PERAN SERTA MASYARAKAT DALAM PEMILU
}

\author{
Arry Dharmawan Trissatya Putra \\ Sekretariat KPU DIY Bagian Umum dan Logistik \\ E-mail: arrydharmawan@gmail.com
}

\begin{abstract}
ABSTRAK
Sosialisasi Pemilu dilaksanakan oleh Penyelenggara Pemilu sebagai upaya dalam meningkatkan peran serta masyarakat dalam Pemilu dan mewujudkan Pemilu yang berintegritas. Namun permasalahan mengenai sosialisasi terutama partisipasi masyarakat dalam Pemilu yang dilakukan secara luas dan efektif yang akan menentukan kualitas partisipasi pemilih masih menjadi pekerjaan rumah tersendiri bagi Penyelenggara Pemilu. Untuk itu diperlukan inovasi model sosialisasi Pemilu yang bisa diterapkan dalam Pemilu yang akan datang untuk meningkatkan kualitas Pemilu di Indonesia. Metode kualitatif dipilih dalam penelitian ini untuk melihat peran sosialisasi yang sudah dan inovasi yang harus dilakukan oleh KPU dalam rangka meningkatkan peran serta masyarakat dalam Pemilu.
\end{abstract}

Kata kunci: Sosialisasi, Partisipasi, Pemilu, Inovasi

\section{INNOVATION OF SOCIALIZATION CITIZEN PARTICIPATION MODEL IN ELECTION}

\begin{abstract}
Political socialization was conducted by Electoral Committee as an attempt to foster public participation in the election of integrity. However, there are some factors impeding public participation which need to be overcome by the electoral committee. Therefore, innovative model of political socialization is needed to improve the quality of future election in Indonesia. Qualitative method is employed in this study to investigate the role of current political socialization and to find out innovative way which should be undertaken by electoral committtee to foster public participation in the election.
\end{abstract}

Keywords: socialization, participation, election, innovation

\section{PENDAHULUAN}

Pemilihan Umum (Pemilu) merupakan salah satu pilar demokrasi sebagai sarana perwujudan kedaulatan rakyat guna menghasilkan pemerintahan yang demokratis. Pemerintahan yang dihasilkan dari Pemilu diharapkan menjadi pemerintahan yang mendapat legitimasi yang kuat dan amanah. Pemilu pun menjadi tonggak tegaknya demokrasi, di mana rakyat secara langsung terlibat aktif dalam menentukan arah dan kebijakan politik negara untuk satu periode pemerintahan ke depan.

Dalam hubungannya dengan demokrasi, partisipasi politik berpengaruh terhadap legitimasi masyarakat terhadap jalannya suatu pemerintahan .Dalam suatu Pemilu misalnya partisipasi politik berpengaruh terhadap legitimasi masyarakat kepada pasangan calon yangterpilih.Setiap masyarakat memiliki preferensi dan kepentingan masing-masing untuk menentukan pilihan mereka dalam Pemilu. Bisa dikatakan bahwa masa depan pejabat public yang terpilih dalam suatu Pemilu tergantung pada preferensi masyarakat sebagai pemilih.

Tidak hanya itu, partisipasi politik masyarakat dalam Pemilu dapat dipandang sebagai kontrol masyarakat terhadap suatu pemerintahan. Kontrol yang diberikan beragam tergantung dengan tingkat partisipasi politik masing-masing. Selain sebagai inti dari demokrasi, partisipasi politik juga berkaitan erat dengan pemenuhan hak-hak politik warga negara. Wujud dari pemenuhan hak-hak politik adalah adanya kebebasan bagi setiap warga untuk 
menyatakan pendapat danberkumpul. Seperti yang tertuang dalam UUD 1945 pasal 28: "kemerdekaan berserikat danberkumpul mengeluarkan pikiran dengan lisan dan tulisan dan sebagainya ditetapkan dengan undang-undang" (Tia Subekti, 2014).

Keberhasilan Pemilu dipengaruhi oleh tingkat kesadaran politik warga negara yang bersangkutan. Kesadaran politik ini terefleksi dari seberapa besar partisipasi dan peran masyarakat dalam proses Pemilu, dengan memberikan kesempatan kepada setiap warga negara untuk memberikan suara dukungannya dalam proses penetapan pemerintah baik dieksekutif maupun legislatif selaku pemangku kebijakan. Pada dasarnya partisipasi politik masyarakat dalam Pemilu dapat menjadi sarana bagi masyarakat dalam mengontrol jalannya pemerintah yang akan terpilih. Masyarakat berhak untuk menentukan dan menyerahkan amanahnya kepada mereka yang layak dan dipercaya untuk menjalankan roda pemerintahankedepan.

Selain itu partisipasi politik masyarakat juga dapat menjadi alat untuk mengekspresikan eksistensi individu atau kelompok sosial di masyarakat dengan mempengaruhi pemerintah melalui mekanisme politik. Rendahnya partisipasi politik umumnya muncul karena sikap apatis dan sikap apriori terhadap aktifitas dan kegiatan politik, dimana masyarakat lebih memilih untuk menjalankan aktivitas harian mereka seperti bekerja, berolahraga, klub sosial, bertamasya dan sebagainya, yang dirasa dapat memberikan suatu manfaat yang lebih nyata dibandingkan dengan harus berpartisipasi dalam politik.

Faktor lain yang juga erat kaitannya dengan partisipasi politik adalah dengan tingkat pendidikan masyarakat, dimana semakin tinggi tingkat pendidikan masyarakat, biasanya akan berbanding lurus dengan kecenderungan mereka untuk berpartisipasi dalam politik. Inilah yang menjadi ironi di banyak negara berkembang, dimana tingkat literasi masyarakat yang masih rendah, sehingga berimbas pada tingkat partisipasi masyarakat pada agenda politik yang umumnya tergolong rendah (Putri, 2015).

Permasalahan penyelenggara Pemilu yang banyak terjadi dalam pelaksanaan Pemilu adalah menyangkut integritas penyelenggara Pemilu yaitu berupa besarnya intervensi Kepala Desa dan Camat dalam menentukan calon anggota
KPPS, PPS, PPK dimana seharusnya hal tersebut menjadi tanggung jawab penyelenggara atau KPUD yang semestinya berperan. Akibatnya potensi penyimpangan penyelenggara pemilihan di level paling bawah cukup besar. (ERI, 2015). Pelanggaran-pelanggaran tersebut tidak mendidik masyarakat untuk menyalurkan aspirasi dan suara mereka dengan benar. Sehingga menyebabkan turunnya demokrasi elektoral di Indonesia. Mata rantai ini kuat sekali, elite partai dan peserta Pemilu bekerja sama dengan pelaksana bermain-main dalam lingkaran setan yang memunculkan fenomena dan peraturan prinsip dari kondisi yang menyebabkan turunnya demokrasi elektoral kita (Kotarumalos, 2014).

Dengan demikian masyarakat perlu mengetahui dan memahami berbagai hal yang terkait dengan Pemilu. Misalnya untuk apa Pemilu diselenggarakan, apa saja tahapan Pemilu, siapa saja yang boleh ikut serta dalam Pemilu, bagaimana tatacara menggunakan hak pilih dalam Pemilu dan sebagainya. Pertanyaan itu penting diajukan agar masyarakat menjadi pemilih cerdas dalam menentukan pilihan politiknya dan aktif terlibat dalam setiap penyelenggaraan Pemilu.Oleh karena itu, perlu adanya sosialisasi. Dengan adanya sosialisasi diharapkan semakin menyadarkan masyarakat tentang pentingnya menggunakan hak suara karena Pemilu merupakan proses demokrasi yang menentukan arah jalannya pemerintahan dan kemajuan bangsa. Pemahaman kesadaran berpolitik bagi masyarakat perlu diaktualisasikan melalui pembelajaran yang melibatkan masyarakat secara langsung.

Dari uraian tersebut menunjukkan bahwa salahsatu peran strategis KPU adalah meningkatkan kesadaran politik rakyat untuk berpartisipasiaktifdalam setiap proses pemilihan umum, dengan demikian diperlukan suatu upaya sistematis bagi lembaga KPU untuk melakukan model sosialisasi yang tepat kepada masyarakat dalam rangka membangun kesadaran politik masyarakat sehingga dapat menciptakan proses demokratisasi di Indonesia.

Makalah ini lebih menitikberatkan pada elemen-elemen sosialisasi yaitu tentang keterlibatan masyarakat sebagai penyelenggara Pemilu secara ad-hoc dimana ditemukan banyak permasalahan mengenai rendahnya minat masyarakat. Keadaan tersebut seharusnya menjadi fokus tersendiri bagi lembaga penyelenggara Pemilu. 
Kemudian, sosialisasi mengenai pembe-lajaran atau proses pemungutan suara, menurut penulis sudah seharusnya dilakukan setiap tahun dalam semua jenjang pendidikan di Indonesia, dan bukan dilaksanakan pada masa tahapan pemilihan saja. Hal ini menjadi sangat penting untuk memberikan gambaran pada generasi muda tentang demokrasi dan bagaimana tata cara pemungutan suara yang benar, sehingga kondisi ini dapat menjadi budaya baru dalam pendidikan politik masyarakat.

Berdasarkan latar belakang yang telah disusun di atas maka dapat ditarik beberapa identifikasi permasalahan yang timbul dari sosialisasi yang telah dilakukan oleh KPU, antara lain: Bagaimana efektifitas sosialisasi Pemilu oleh Penyelenggara Pemilu dalam mewujudkan Pemilu yang berintegritas.Bagaimana inovasi model sosialisasi Pemilu yang akan datang dalam meningkatkan kualitas Pemilu di Indonesia?

\section{KERANGKA TEORI}

Dalam penelitian yang bersifat ilmiah diperlukan teori sebagai pedoman dan landasan bagi penulis untuk dapat menyusun makalah ini. Oleh karena itu, penulis mengemukakan beberapa pengertian dari teori-teori yang berhubungan langsung dengan makalah ini yang berfungsi untuk memberikan batasan atau gambaran yang jelas dari penelitian yang dilakukan

\section{Sosialisasi}

Sosialisasi merupakan suatu proses dimana seseorang melakukan internalisasi konsep, nilainilai, ide atau gagasan kepada orang lain dalam suatu kelompok atau institusi sosial sehingga memunculkan partisipasi (keikutsertaan) di dalam kelompok atau institusi sosial tersebut. James W. Vander Zanden (dalam Damsar: 2010: 152) mendefenisikan sosialisasi sebagai "suatu proses interaksi sosial dengan mana orang memperoleh pengetahuan, sikap, nilai, dan perilaku essensial untuk keikutsertaan (partisipasi) efektif dalam masyarakat

Sosialisasi diartikan sebagai sebuah proses seumur hidup bagaimana seorang individu mempelajari kebiasaan-kebiasaan yang meliputi cara-cara hidup, nilai-nilai, dan norma-norma sosial yang terdapat dalam masyarakat agar dapat diterima oleh masyarakatnya. Secara umum sosialisasi didefinisikan sebagai proses penanaman atau transfer kebiasaan atau nilai dan aturan dari satu generasi kegenerasi lainnya dalam sebuah kelompok atau masyarakat. Sosialisasi juga dikenal sebagai teori menge-nai peranan (role theory). Karena dalam prosessosialisasi diajarkan peran-peran yang harus dijalankan oleh individu.

\section{Sosialisasi Politik}

Sosialisasi politik, menurut Hyman merupakan suatu proses belajar yang kontinyu yang melibatkan baik belajar secara emosional (emotional learning) maupun indoktrinasi politik yang manifes (nyata) dan dimediai (sarana komunikasi) oleh segala partisipasi dan pengalaman si individu yang menjalaninya. Pengertian sosialisasi politik secara sederhana dapat dipahami melalui menambahkan atau mengaitkan definisi yang ada tentang sosialisasi dengan politik. Jika didefenisikan dengan mengaitkan pengertian sosialisasi dengan politik, maka sosialisasi politik dapat diartikan sebagai suatu proses melakukan internalisasi konsep, nilai-nilai, ide atau gagasan, pengetahuan, sikap dan perilaku untuk memunculkan keikutsertaan (partisipasi) efektif di dalam kelompok atau institusi politik.

Sedangkan apabila defenisi sosiologi politik dikonstruksi berdasarkan kesimpulan kita tentang sosialisasi di atas, maka sosialisasi politik adalah suatu transmisi pengetahuan, sikap, nilai, norma dan perilaku essensial dalam kaitannya dengan politik, agar mampu berpartisipasi efektif dalam kehidupan politik (Damsar: 2010: 153). Berdasarkan pengertian tersebut, dapat dikatakan bahwa dalam prosessosialisasi politik ada suatu upaya yang dilakukan oleh seseorang atau kelompokguna memberikan suatu penanaman atau internalisasi suatu gagasan atau nilai-nilai politik kepada orang lain (masyarakat) agar nantinya memunculkan suatusikap politik (partispasi) suatu masyarakat atau institusi.

\section{Partisipasi Politik}

Partisipasi politik secara harafiah berarti keikutsertaan, dalam kontekspolitik hal ini mengacu pada pada keikutsertaan warga dalam berbagai proses politik. Pengertian partisipasi politik adalah kegiatan warganegara yang 
bertujuan untuk mempengaruhi pengambilan keputusan politik

Peran serta atau partisipasi masyarakat dalam politik adalah kegiatan seseorang atau sekelompok orang untuk turut serta secara aktif dalam kehidupan politik, dengan jalan memilih pimpinan negara, dan secara langsung atau tidak langsung mempengaruhi kebijakan pemerintah, 'public policy'. Secara konvensional kegiatan ini mencakup tindakan seperti: memberikan suara dalam pemilihan umum, 'voting'; menghadiri rapat umum, 'campaign'; menjadi anggota suatu partai atau kelompok kepentingan; mengadakan pendekatan atau hubungan, 'contacting'dengan pejabat pemerintah, atau anggota parlemen dan sebagainya (Budiardjo, 2009).

Partisipasi bisa bersifat individual atau kolektif, terorganisir atau spontan, mantap atau sporadik, secara damai atau dengan kekerasan, legal atau ilegal, efektif atau tidak efektif. Fungsi utama partai politik adalah mencari dan mempertahankan kekuasaan guna mewujudkan program-programnya berdasarkan ideologi tertentu. Cara yang digunakan partai politik dalam sistem politik demokratis untuk mendapatkan dan/atau mempertahankan kekuasaan itu adalah dengan melalui mekanisme pemilihan umum. Terkait dengan tugas tersebut maka menjadi tugas partai politik untuk mencari dukungan seluas-luasnya dari masyarakat agar tujuan itu dapat tercapai.

Demikian pula halnya jika seseorang mau terlibat aktif dalam kegiatan pertisipasi politik menurut Davis terdapat tiga unsur, yaitu: (1) Adanya penyertaan pikiran dan perasaan, (2) adanya motivasi untuk berkontribusi, serta (3) adanya tanggung jawab bersama (Davis \& Newstrom, 1996). Karena esensinya partisipasi berasal dari dalam atau dari diri sendiri masyarakat tersebut. Artinya meskipun diberi kesempatan oleh pemerintah atau Negara tetapi kalau kemauan ataupun kemampuan tidak ada maka partisipasi tidak akan terwujud.

Kesempatan berpartisipasi berasal dari luar masyarakat. Demikian pula walaupun kemauan dan kemampuan berpartisipasi oleh masyarakat ada tetapi kalau tidak diberi kesempatan oleh pemerintah Negara maka partisipasi tidak akan terjadi. Oleh karena itu tiga hal tersebut kemauan, kemampuan maupun kesempatan merupakan factor yang sangat penting dalam mewujudkan partisipasi.
Meningkatnya keterlibatan masyarakat dalam penyelenggaraan Pemilihan Umum, menunjukan semakin kuatnya tatanan demokrasi dalam sebuah negara. Demokrasi menghendaki adanya keterlibatan rakyat dalam setiap penyelenggaraan yang dilakukan negara. Rakyat diposisikan sebagai aktor penting dalam tatanan demokrasi, karena pada hakekatnya demokrasi mendasarkan pada logika persamaan dan gagasan bahwa pemerintah memerlukan persetujuan dari yang diperintah. Keterlibatan masyarakat menjadi unsur dasar dalam demokrasi. Untuk itu, penyelenggaraan Pemilu sebagai sarana dalam melaksanakan demokrasi, tentu saja tidak boleh dilepaskan dari adanya keterlibatan masyarakat.

Partisipasi politik tidak lebih dari keterlibatan individu sampai pada bermacam-macam tingkatan, atau juga dijelaskan secara subtantif bisa berarti upaya atau usaha terorganisir oleh konstituen atau warga Negara yang baik untuk memilih para pemimpin yang mereka nilai baik juga. Partispasi ini mereka melakukannya dengan penuh tanggung jawab terhadap kehidupan bersama dalam lingkup suatu bangsa dan negara. Partisipasi politik ditekankan pada aspek untuk mendukung kepentingan-kepentingan atau visi dan misi elit politik tetentu.Dengan demikian, secara tidak langsung kita akan menentukan pembuat kebijakan yang akan berusaha mensejahterakan masyarakat secara umum.

\section{Inovasi}

Inovasi adalah kegiatan penelitian, pengembangan, dan/atau perekayasaan yang bertujuan mengembangkan penerapan praktis nilai dan konteks ilmu pengetahuan yang baru, atau cara baru untuk menerapkan ilmu pengetahuan dan teknologi yang telah ada ke dalam produk atau proses produksi.(Undang Undang No. 18 tahun 2002 Sistem Nasional Penelitian, Pengembangan, Dan Penerapan Ilmu Pengetahuan dan Teknologi, 2002)

Secara harfiah inovasi / innovation berasal dari kata to innovate yangmempunyai arti membuat perubahan atau memperkenalkan sesuatu yang baru,inovasi kadang diartikan sebagai penemuan namun, maknanya berbeda dengan penemuan dalam arti discovery atau Invention. Discovery mempunyai maknapenemuan sesuatu yang sebenarnya sudah ada sebelumnya, misalnya penggunaanmodel sosialisasi dalam tahapan 
Pemilu, untukmeningkatkan kualitas Pemilu itu sendiri, sebenarnya model sosialisasi tersebut sudah dilaksanakan dinegara-negara lain. Dan dengan kajian yang menyeluruh bisa diasumsikan untuk diterapkan di Indonesia

Istilah inovasi dalam organisasi pertama kali diperkenalkan oleh Schumpeter pada tahun 1934. Inovasi dipandang sebagai kreasi dan implementasi 'kombinasi baru'. Istilah kombinasi baru ini dapat merujuk pada produk, jasa, proses kerja, pasar, kebijakan dan sistem baru. Dalam inovasi dapat diciptakan nilai tambah, baik pada organisasi, pemegang saham, maupun masyarakat luas.Oleh karenanya sebagian besar definisi dari inovasi meliputi pengembangan dan implementasi sesuatu yang baru (dalam de Jong \& den Hartog, 2003) sedangkan istilah 'baru' dijelaskan Adair(1996) bukan berarti original tetapi lebih ke newness (kebaruan).Arti kebaruan ini, diperjelas oleh pendapat Schumpeter bahwa inovasi adalah mengkreasikan dan mengimplementasikan sesuatu menjadi satu kombinasi.

Dengan inovasi maka seseorang dapat menambahkan nilai dari produk, pelayanan, proses kerja, pemasaran, sistem pengiriman, dan kebijakan, tidak hanya bagi perusahaan tapi juga stakeholder dan masyarakat (dalam de Jong \& Den Hartog, 2003). 'Kebaruan' juga terkait dimensi ruang dan waktu.'Kebaruan' terikat dengan dimensi ruang. Artinya, suatu produk atau jasa akan dipandang sebagai sesuatu yang baru di suatu tempat tetapi bukan barang baru lagi di tempat yang lain. Namun demikian, dimensi jarak ini telah dijembatani oleh kemajuan teknologi informasi yang sangat dahsyat sehingga dimensi jarak dipersempit. Implikasinya, ketika suatu penemuan baru diperkenalkan kepada suatu masyarakat tertentu, maka dalam waktuyang singkat, masyarakat dunia akan mengetahuinya. Dengan demikian 'kebaruan'relatif lebih bersifat universal. 'Kebaruan' terikat dengan dimensi waktu.Artinya, kebaruan di jamannya. Jika ditengok sejarah peradaban bangsa Indoensia, maka pada jaman tersebut maka bangunan candi Borobudur, pembuatan keris oleh empu, pembuatan batik adalah suatu karya bersifat inovatif di jamannya

\section{Pendidikan Politik}

Istilah Pendidikan Politik berasal dari bahasa inggris yaitu, Political socialization.
Jika ditelusuri pada berbagai literatur politik yang ada Pendidikan Politik termasuk bagian prosessosialisasi politik. Walaupun berbeda secara penulisan, baik sosialisasi politik mau pun pendidikan politik mempunyai tujuan serta fungsi yang sama secara prinsip. Karena itu dalam penulisan ini baik sosialisasi politik ataupun pendidikan politik dipergunakan bersamatanpa diperdebatkan.

Menurut Rusadi Kantaprawira (2004:55), pendidikan politik yaitu untuk meningkatkan pengetahuan rakyat agar mereka dapat berpartisipasi secara maksimal dalam sistem politiknya. Sesuai paham kedaulatan rakyat atau demokrasi, rakyat harus mampu menjalankan tugas partisipasi.Selanjutnya untuk tujuan pendidikan politik bagi generasi muda dituangkan dalam Inpres No. 12 Tahun 1982 tentang Pendidikan Politik bagi Generasi Muda yang menyatakan bahwa: Tujuan pendidikan politik adalah memberikan pedoman kepada generasi muda Indonesiaguna meningkatkan kesadaran kehidupan berbangsa dan bernegara. Sedangkan tujuan pendidikan politik lainnya ialah menciptakan generasi muda Indonesia yang sadar akankehidupan berbangsa dan bernegara berdasarkan Pancasila dan UUD 1945 sebagai salah satu usaha untuk membangun manusia Indonesia seutuhnya.

\section{HASIL DAN PEMBAHASAN}

Salah satu Bab yang terkandung dalam Undang-Undang Nomor 8 Tahun 2012 tentang Pemilu Anggota DPR, DPD dan DPRD adalah Partisipasi Masyarakat dalam Penyelenggaraan Pemilu (Bab XIX). Dengan demikian empat unsur penting proses penyelenggaraan Pemilu, yaitu Pemilih, Peserta Pemilu, Penyelenggara Pemilu, dan partisipasi Organisasi Masyarakat Sipil, telah dipenuhi. Bentuk partisipasi masyarakat yang disebutkan dalam Pasal 246 tersebut adalah sosialiasi Pemilu, pendidikan politik bagi Pemilih, survey atau jajak pendapat tentang Pemilu, dan penghitungan cepat (Quick Count) hasil Pemilu.

Terdapat macam bentuk kegiatan yang dikategorikan sebagai partisipasi unsur masyarakat dalam proses penyelenggaraan Pemilu. Yang dimaksud dengan masyarakat di sini adalah unsur-unsur masyarakat di luar lembaga legislatif, eksekutif, judikatif, dan lembaga 
negara lainnya, yaitu individu warga negara, kelompok atau forum, organisasi kemasyarakatan, partai politik, media massa baik cetak maupun elektronik, lembaga swadaya masyarakat, dan organisasi masyarakat sipil lainnya. Kegiatan yang dilakukan oleh penyelenggara Pemilu, DPR dan DPRD, aparat Pemerintah, dan lembaga judikatif tidak dapat dikategorikan sebagai partisipasi masyarakat karena apa yang dikerjakan lembaga tersebut merupakan tugas sehari-hari (melaksanakan tugas dan kewenangan sebagailembaga negara) sesuai dengan peraturan perundang-undangan. (Surbakti \& Supriyanto, 2013)

Adanya beberapa konsep dan sarana bagi partisipasi masyarakat tentu saja perlu untuk dimaksimalkan. Pertama, hal yang perlu dilakukan adalah memaksimalkan proses sosialisasi tentang pentingnya Pemilu dalam sebuah Negara yang demokratis, bukan hanya sosialisasi teknis penyelenggaraan Pemilu. Meskipun dalam ketentuan undang-undang menyatakan bahwa sosialisasi dilakukan terkait dengan teknis penyelenggaraan Pemilu, namun sosialisasi segala hal yang melatarbelakangi penyelenggaraan Pemilu perlu untuk dilakukan. Hal ini menjadi penting karena penanaman pemahaman terkait dengan esensi dan kaidahkaidah demokrasi merupakan inti penggerak semangat masyarakat untuk terus menjaga demokrasi dan penyelenggaraan Pemilu di Negara ini (Asshiddiqie, 2005).

Penyelenggara Pemilu mempunyai tugas untuk melakukan sosialisasi Pemilu, hal ini tidak saja karena KPU-lah yang membuat peraturan pelaksanaan tentang tata cara setiap tahapan Pemilu tetapi juga karena KPU dan aparatnya di daerahlah yang melaksanakan seluruh tata cara Pemilu tersebut. Akan tetapi program sosialisasi Pemilu mencakup kegiatan yang sangat luas tidak hanya karena mencakup seluruh tahap proses penyelenggaraan Pemilu tetapi juga perlu disampaikan kepada semua pemangku kepentingan di seluruh wilayah Indonesia.

Dalam melaksanakan sosialisasi Pemilu, KPU berpegang pada Kode Etik Pelaksana Pemilihan Umum agar hasil kerjanya dipercayai publik. Pelaksanaan tugas dan kewenangan penyelenggara pemilihan umum harus bertindak independen, nonpartisan, tidak memihak. Untuk mewujudkan sikap independen, nonpartisan, dan tidak memihak itu, penyelenggara pemilihan umum harus melaksanakan pemilihan umum berdasarkan peraturan perundang-undangan dan mematuhi Kode Etik Pelaksana Pemilihan Umum.

Peran KPU dalam sosialisasi politik ditegaskan dalam UU Pemilu No. 22 Tahun 2007 tentang Penyelenggara Pemilihan Umum pada pasal 8 ayat (1) huruf q: melaksanakan sosialisasi mengenai penyelenggaraan Pemilu yang berkenaan dengan tugas dan wewenang KPU kepada masyarakat. Khusus untuk KPUD kabupaten/ kota, perannya dalam sosialisasi ditegaskan dalam pasal 10 huruf o: melaksanakan sosialisasi mengenai penyelenggaraan Pemilu dan atau yang berkenaan dengan tugas dan wewenang KPU kapubaten/ kota kepada masyarakat. Untuk menjalankan tugas di bidang sosialisasi tersebut, secara struktural KPU telah menjangkau semua tingkatan wilayah dan geografis karena di setiap wilayah dibentuk kepanjangan tangan KPU. Pada wilayah propinsi terdapat KPUD Propinsi, di wilayah Kabupaten/kota dibentuk KPUD kabupaten/kota, di tingkat wilayah kecamatan dibentuk PPK (Panitia Pemilihan Kecamatan), di tingkat Desa/kelurahan terdapat PPS (Panitia Pemungutan Suara). Pada saat pemungutan suara, di tiap-tiap TPS terdapat KPPS (Kelompok Penyelenggara Pemungutan Suara). Sedangkan untuk pemungutan suara di luar negeri dilaksanakan oleh PPLN (Panitia Pemungutan Luar Negeri). Pesan-pesan dalam kegiatan sosialisasi perlu dilakukan secara menarik, informatif, sederhana, dan mudah dipahami.

Permasalahan sosialisasi yang selama ini dilakukan oleh KPU adalah, sosialisasi hanya menyasar pada lingkup tahapan Pemilu yang menjadi fokus pendidikan pemilih dan sangat terbatas. Yaitu hanya mencakup pendaftaran/ pemutahiran daftar pemilih, faktor apa saja yang perlu dipertimbangkan dalam menentukan sikap memilih atau tidak memilih dan memberikan suara kepada siapa, dan pemungutan dan penghitungan suara di TPS. Pengetahuan yang ditransfer mengenai pendaftaran pemilih bukan apa saja yang menjadi syarat menjadi pemilih, bagaimana, kapan dan di mana mendaftarkan diri sebagai pemilih tetapi terutama mengapa mendaftarkan diri sebagai pemilih. Pengetahuan yang dialihkan kepada warga bukan apa, bagaimana, kapan dan di mana memberikan 
suara secara sah melainkan mengapa harus memilih, mengapa sejumlah isu tertentu tentang kebijakan publik perlu dipertimbangkan dalam menentukan sikap memberikan suara kepada suatu partai/calon.

Sosialisasi yang dilakukan oleh KPU dianggap lebih fokus pada hari-H saja dan kurang membumikan pentingnya substansi Pemilu itu sendiri, yaitu tentang apa, siapa dan bagaimana Pemilu yang berkualitas dan berintegritas. Dengan kata lain, sosialisasi yang dilakukan KPU dianggap belum menyentuh wilayah substansi, masyarakat belum merasakan tercerahkan dan teredukasi secara memadai. Jika ini dibiarkan dan tidak diantisipasi maka sangat dimungkinkan banyak praktek kecurangan akan kembali terulang.

KPU sampai dengan saat ini masih mempertahankan model sosialisasi konvensional dan hanya dilakukan pada saat menjelang Pemilu ataupun Pemilukada. Hal ini mungkin disebabkan bahwa KPU hanya ingin mengejar voter's turnout sebagai salah satu indicator suksesnya Pemilu tersebut dilaksanakan. Meskipun hal ini merupakan hal yang wajar, karena voter'sturnout bisa dirujuk sebagai seberapa besar masyarakat mengambil bagian dalam menggunakan hak suaranya dibanding dengan warga negara yang berhak memilih seluruhnya. Namun hal ini menjadi bias jika pada akhirnya, Pemilu tersebut tidak demokratis dan kurang berintegritas.

Hal ini menjadi masalah tersendiri dimana faktayang berada dilapangan menyatakan bahwa penyelenggara Pemilu di tingkat $a d-h o c$ dirasa kurang capable dan merupakan orang yang ituitu saja, dan biasanya merupakan rekomendasi Camat/Kades atau sebutan lainnya. Meskipun hal ini telah diantisipasi oleh KPU dengan membuat PKPU tentang syarat-syarat yang harus dipenuhi untuk menjadi penyelenggara di tingkat ad-hoc.Namun sepertinya masih banyak pekerjaan rumah selain hanya membuat PKPU ini, hal ini merupakan gambaran bahwa masih banyaknya pelanggaran Pemilu yang dilakukan oleh penyelenggara Pemilu di tingkat bawah.

Contoh kasus, dalam Pemilukada 2015 yang lalu, untuk menyeleksi badan ad hoc yang sesuai dengan syarat PKPU ternyata cukup sulit diterapkan di lapangan. Bahkan beberapa daerah harus melakukan perpanjangan waktu pendaftaran. Pertanyaan yang muncul adalah bagaimana sebenarnya sosialisasi yang telah dilakukan KPU untuk hal ini? Apakah dirasa cukup hanya dengan memberikan pengumuman melalui selebaran yang kemudian ditempel di papan pengumuman kantor desa ataupun di kantor KPU setempat? Dari sudut pandang penulis, hal ini merupakan blunder fatal dimana ketika kebijakan dibuat, secara formalitas hanya dilaksanakan oleh KPU untuk diteruskan hingga level desa ibarat kata dalam manajemen, tidak hanya cukup bisa memproduksi barang ataupun jasa namun yang tidak kalah penting adalah bagaimana menjual atau mendistribusikan barang / jasa tersebut "The goal of management is to remove obstacles" (Orfalea, 2007)

Bagaimana mungkin KPU sebagai penyelenggara Pemilu seolah lalai mencari kapanjangan tangan mereka sendiri. Perlu disadari bahwa salah satu elemen Pemilu yang berintegritas adalah penyelenggara Pemiluyang berintegritas (Annan, 2012). Sudah menjadi kewajiban KPU untuk memberikan informasi ataupun sosialisasi tentang "kehormatan" menjadi bagian dari penyelenggara Pemilu itu sendiri. Kehormatan disini adalah apa yang dilakukan saat ini, tidak lain adalah ikut menentukan nasib bangsa ataupun daerahnya. KPU bisa dengan lebih masif memberikan sosialisasi ini kepada masyarakat dengan turun langsung hingga level desa untuk menjaring sumber daya yang kompeten untuk mendukung suksesnya penyelenggaraan Pemilu.

Adanya kekhawatiran bahwa badan adhoc tidak mandiri dikarenakan rekrutmen PPS dan KPPS hanya penunjukkan. Pasal 19 (ayat 2) UU No 8 tahun 2015 tentang Pemilihan Gubernur, Bupati dan Walikota: "Anggota PPS diangkat oleh KPU Kabupaten/Kota atas usul bersama Kepala Desa atau sebutan lain/Lurah dan Badan Permusyawaratan Desa atau sebutan lain/Dewan Kelurahan”. Karena dalam praktiknya, Kepala Desa/Lurah dan BPD hanya mengusulkan nama-nama yang "dekat" dengan mereka. Tak jarang, makna "dekat" di sini bukan hanya dalam artian personal, tapi juga dalam artian politis, yakni memiliki pandangan politik yang sama dengan Kades. Akhirnya, KPU Kabupaten tidak punya banyak pilihan terhadap nama-nama yang diusulkan oleh Kades. Kemudian Pasal 21 (ayat 2) UU No 8 tahun 2015: "Anggota KPPS diangkat dan diberhentikan oleh PPS atas nama Ketua KPU Kabupaten/Kota. Dalam praktiknya, 
PPS berkoordinasi dengan Dukuh/sebutan lain, untuk memberi masukan nama-nama calon KPPS. Faktanya, Dukuh hanya mengusulkan nama-nama yang dekat dengan mereka atau yang sudah terbiasa menjadi KPPS sebelumnya.

Marwanto, seorang anggota KPU Kabupaten Kulonprogo DIY, dalam tulisannya Regenerasi BadanAd-Hoc Pemilu, menjelaskan bahwa regulasi dalam UUini mengandung kelemahan. Pertama, menghambat regenerasi penyelenggara Pemilu di tingkat bawah. Dalam arti, warga yang punya keinginan dan potensi, tapi tidak dekat dengan Kades dan Dukuh, sulit mendapat akses untuk menjadi PPS maupun KPPS.Kedua, bisa menjadi celah bagi masuknya kepentingan politik. Tidak dipungkiri lagi, posisi Kades amat dekat dengan politik praktis. Pada Pileg 2014 kemarin, fakta menunjukkan sangat banyak Kades yang maju menjadi calon legislatif (Caleg). Meski saat menjadi Caleg ia sudah mengundurkan diri, tapi jaringan sebagai tokoh sentral di desa tidak bisa serta merta diputus begitu saja. Dan jaringan tersebut bisa digunakan sebagai penyelenggara ad-hoc (Marwanto, 2015)

Untuk mengantisipasi kelemahan pertama, KPU lewat Peraturan KPU No. 3 tahun 2015 tentang Tata Kerja KPU Provinsi, KPU Kabupaten, PPK, PPS dan KPPS, pasal 18 (ayat1, huruf k), menyebutkan salah satu syarat menjadi PPK, PPS dan KPPS: "Belum pernah menjabat 2 (dua) kali sebagai anggota PPK, PPS, dan KPPS". Dilihat dari aspek terjaminya regenerasi penyelenggara ad-hoc, pasal ini sangat bagus. Tapi yang perlu diantisipasi adalah jika kurangnya minat menjadi PPK, PPS dan KPPS. Sebab berkiprah sebagai PPK, PPS dan KPPS selama ini identik dengan pengabdian. Dan pengabdian itu telah ditunjukkan oleh mereka yang sudah berkali-kali menjadi PPK, PPS dan KPPS.

Memang hal ini menjadi tantangan jika dilihat dari Pemilu sebelumnya PPS dan KPPS merupakan pengabdian, namun dalam pandangan penulis, batasan 2 (dua) kali ini sangatlah baik untuk proses regenerasi, sehingga memberikan pengalaman baru bagi masyarakat yang belum pernah menjadi PPK, PPS ataupun KPPS. Dan apabila terjadi kesulitan dalam hal terganjal persyaratan 2 (dua) kali ini pun sebenarnya telah diantisipasi dalam PKPU no. 3 tahun 2015, pasal 18 ayat 4 disebutkan bahwa "Dalam hal persyaratan sebagaimana dimaksud pada ayat (1) hurufk tidak dapat dipenuhi, KPU/ KIP Kabupaten/Kota dapat bekerjasama dengan lembaga pendidikan atau tenaga pendidik untuk memeroleh anggota PPK,PPS dan KPPS yang memenuhi persyaratan." Tinggal bagaimana KPU/ KIP Kabupaten/Kota lebih aktif dalam melaksanakan ketentuan ini. Dari sudut pandang penulis apabila ada yang mungkin bisa dihilangkan dari PKPU ini mungkin hanyalah batasan usia minimal dan tingkat pendidikan minimal. Penulis merasa bahwa, usia minimal mungkin bisa lebih diturunkan lagi hingga mencapai usia rata-rata mahasiswa lulus bergelar sarjana, hal ini merujuk konsep bahwa sarjana baru memiliki kemampuan komunikatif, memiliki semangat penggerak dan antusiasme yang tinggi. (Nagano, 2012). Council of British Industry (CBI) menyatakan bahwa sarjana baru memiliki sikap positif sebagai faktor kunci mendasari kinerja mereka. Kesiapan untuk mengambil bagian dan berkontribusi, keterbukaan terhadap ide-ide baru dan dorongan untuk membuat hal tersebut terjadi. Mereka mencatat bahwa pengusaha menghargai sarjana baru dapat menunjukkan kewirausahaan dan pendekatan inovatif, dan berpikir kreatif yang membawa perspektif segar dan mempunyai banyak asumsi.(Lowden, Hall, Elliot, \& Lewin, 2011)

Kemudian untuk tingkat pendidikan minimal, penulis berasumsi untuk menghilangkan pasal ini kemudian diganti cukup dengan mampu dan cakap membaca, menulis dan berhitung yang dibuktikan dengan surat keterangan, meskipun sebenarnya hal ini telah diatur dalam PKPU no. 3 tahun 2015, pasal 18 ayat 3, namun dalam PKPU tersebut tertulis hanya untuk KPPS "Dalam hal persyaratan pendidikan paling rendah sekolah lanjutan tingkat atas atau sederajat sebagaimana dimaksud pada ayat (1) huruf $h$ bagi KPPS tidak dipenuhi, maka dapat diisi oleh orang yang mempunyai kemampuan dan kecakapan membaca, menulis dan berhitung dibuktikan sengan surat pernyataan"

Sementara untuk kelemahan kedua, hal ini nampaknya belum diantisipasi oleh KPU. Solusi yang bisa ditempuh adalah perlu dibukanya akses pendaftaran bagi calon anggota PPS. Memberikan penyuluhan dan pendidikan peran serta masyarakat dalam Pemilu bisa menjadi solusi yang tepat dengan melakukan penyuluhan ke masyarakat yang dilakukan langsung oleh tim dari KPU. Kemudian bisa juga melakukan 
pendaftaran dan bukan bertujuan untuk dilakukan ujiannamun untuk mendapatkan namanama yang tidak diakomodir oleh Kades ataupun Dukuh. Padahal, sebenarnya orang-orang tersebut memiliki kapasitas.

Dengan dilakukannya penyuluhan dan dibukanya akses pendaftaran bagi calon PPS, diharapkan Kades akan mengakomodir lebih banyak lagi potensi warga negara yang punya keinginan dan potensi menjadi PPS. Di sisi lain, KPU Kabupaten/Kota juga akan lebih leluasa untuk menentukan pilihan terkait nama-nama yang akan diangkat sebagai anggota PPS. "It takes a habit to break a habit. You can pray every day for a generous heart, but until you start acting in that direction, nothing 's going to change" (Stanley, 2011).

Diharapkan apabila Sosialisasi Pemilu dapat dilakukan secara meluas dan efektif oleh penyelenggara Pemilu bekerjasama dengan berbagai unsur masyarakat sipil, maka partisipasi pemilih dan berbagai unsur masyarakat dalam proses penyelenggaraan Pemilu akan dapat meningkat. Diperlukan dua hal untuk berpartisipasi dalam proses penyelenggaraan Pemilu, yaitu minat atau kepedulian terhadap Pemilu yang Demokratik, dan pengetahuan tentang tatacara Pemilu. Kegiatan sosialisasi Pemilu bila dipersiapkan dan dilaksanakan secara seksama akan dapat membekali warga masyarakat akan kedua hal itu, setidak-tidaknya pengetahuan tentang tata cara Pemilu. Pendidikan pemilih merupakan proses transfer pengetahuan tentang Pemilu tidak sekedar untuk dapat menjawab pertanyaan apa dan bagaimana Pemilu melainkan terutama untuk menjawab pertanyaan mengapa harus ada Pemilu.

Kemudian. Apabila bentuk partisipasi masyarakat ini dapat dilakukan secara luas dan efektif, maka hal itu ikut menentukan kualitas partisipasi pemilih dalam Pemilu. Karena pendidikan pemilih menyangkut transfer pengetahuan tentang mengapa mendaftarkan diri sebagai pemilih atau mengapa menggunakan hak pilih, maka kegiatan ini lebih tepat dilakukan oleh unsur-unsur organisasi masyarakat sipil yang tidak berafiliasi dengan Peserta Pemilu daripada oleh Penyelenggara Pemilu. Unsurunsur organisasi masyarakat sipil lebih leluasa berbicara kritis.

Perludem dalam kajiannya mengenai "Mendorong Partisipasi Masyarakat dalam
Pemilu 2014", membagi kegiatan sosialisasi menjadi tiga fase yakni:

1.Pengenalan, yangbertujuanuntukmemberikan pengetahuan tetang aspek kePemiluan dengan cara melakukan riset wilayah dan segmentasi pemilih berdasarkan data Pemilu sebelumnya. Kemudian merancang metode dan media sosialisasi sesuai wilayah, segmentasi pemi-lih, serta menyebarluaskan informasi ke Pemiluan sesuai wilayah dan segmentasi pemilih. Fase ini mulai dilakukan 2 tahun sebelum hari pemungutan suara.

(2) Pemantapan, yang bertujuan sebagai penguatan pengetahuan ke-Pemiluan, dengan cara membuat simpul jejaring komunitas berdasarkan wilayah dan segmentasi pemilih dalam melakukan kegiatan penguatan pengetahuan ke-Pemiluan dan penggunaan media massa secara luas khususnya pada satu bulan menjelang pemungutan suara. Fase ini dilakukan sekurang-kurangnya 6 bulan sebelum hari pemungutan suara.

(3) Penentuan, yang bertujuan untuk melakukan monitoring dan evaluasi hasil dan dampak sosialisasi Pemilu, dengan cara melakukan survei singkat terhadap simpul-simpul komunitas untuk melihat hasil dan dampak kegiatan sosialisasi. Kemudian dilanjutkan dengan membuat dan menganalisis data partisipasi pemilih setiap TPS, kecamatan, kabupaten, serta melakukan evaluasi metode dan media sosialisasi yang digunakan untuk merawat dan memperluas simpul jejaring komunitas. Fase ini dilaksanakan setelah hasil Pemilu diumumkan secara berkesinambungan sampai dengan periode pemilihan berikutnya.

Mengacu pada tiga fase tersebut maka kegiatan sosialisasi Pemilu akan menjadi siklus yang berkelanjutan, dan akhirnya menghasilkan penguatan dan pemahaman tentang kePemiluan di masyarakat secara terus menerus. Sosialisasi Pemilu tidak bisa dianggap sebagai kegiatan temporer belaka, tetapi sama pentingnya dengan tahapan penyelenggaraan Pemilu lainnya. Sehingga sangat mendesak bagi KPU khususnya untuk menyiapkan dengan serius strategi sosialisasi Pemilu yang berkelanjutan dan capaian yang terukur pada setiap kegiatannya.

Dengan demikian implementasi partisipasi masyarakat adalah masyarakat merasa tidak lagi menjadi obyek dari kebijakan peme- 
rintah tetapi harus dapat mewakili masyarakat sendiri untuk kepentingan mereka sendiri. Dalam analisis politik modern partisispasi politik merupakan suatu masalah yang penting dan akhir-akhir ini banyak dipelajari terutama hubungannya dengan Negara berkembang. Sebagai definisi umum dapat dikatakan bahwa partisipasi politik adalah kegiatan seseorang atau kelompok orang untuk ikut serta secara aktif dalam kehidupan politik, antara lain dengan jalan memilih pimpinan Negara secara langsung atau tidak langsung, memengaruhi kehidupan kebijakan (public policy) (Budiardjo, 2008).

Inovasi merupakan hal yang wajib dilakukan dalam hal sosialisasi peningkaan peran serta masyarakat dalam Pemilu. Banyak yang percaya bahwa cara-cara baru untuk berkomunikasi dapat membantu menciptakan perubahan sosial (Sheedy, 2011). KPU diwajibkan melakukan sosialisasi tidak hanya sebagai formalitas penyelenggaraan Pemilu, melainkan juga menyangkut informasi mengenai tentang tata cara menjadi bagian dari penyelenggaraan Pemilu itu sendiri. Memberikan informasi via Website atau laman KPU memang sudah dilakukan untuk memfasilitasi informasi terkait peserta Pemilu. Namun website hanya menyentuh kelompok yang memiliki pengetahuan soal internet, karenanya KPU juga harus menyentuh orang-orang di luar golongan tersebut.

Jika website dipilih sebagai salah satu cara sosialisasi untuk informasi, maka sejauh mana KPU sudah mempromosikan websitenya secara masif. Jika permasalahan biaya menjadi faktor penghambat sosialisasi dan informasi maka KPU dapat bersinergi dengan Kemenkominfo danparapemangkukepentingan lainnya. Media social juga bisa menjadi alat sosialisasi bagi KPU. Dan penggunaanya dalam hal sosialisasi bisa merujuk pada Peraturan Menteri Pendayagunaan Aparatur Negara dan Reformasi Birokrasi Republik Indonesia nomor 83 tahun 2012tentang Pedoman Pemanfaatan Media Sosial Instansi Pemerintah.

Hal ini dirasa sangat krusial karena saat ini situs media sosial lebih populer dibandingkan dengan situs web konvensional. Ini disebabkan situs web konvensional dikendalikan oleh satu orang ataupun sebuah organisasi, dan bertujuan untuk menekan serta menyebarkan informasi, namun situs media sosial tidak hanya melakukan kedua hal tersebut, tapi mampu mengundang pengguna untuk melakukan interaksi. Hal ini memberikan gambaran bahwa penggunaan media sosial sebagai penyebar informasi dirasa lebih signifikan memberikan dampak daripada penyebaran informasi secara tradisional. Dengan koran, televisi dan radio yang saat ini mulai ditinggalkan, media sosial memiliki nilai tersendiri karena dirasa lebih mudah dalam mengakses dan menyebarkan informasi.

Bagi KPU sendiri pemanfaatan media sosial yang baik jelas akan mendukung sosialisasi yang lebih efektif dan tentu saja dalam rangka mendukung clean and good governance, dimana semua kegiatan dan sosialisasi bisa dengan mudah dan tanpa biaya disampaikan kepada khalayak ramai. Dalam twitter misalnya, jika seseorang sudah mem-follow akun KPU, maka secara otomatis, segala sesuatu yang di posting oleh akun KPU tersebut akan muncul dihalaman home orang tersebut, dan biasanya mau tidak mau, orang tersebut akan membaca secuplik berita ataupun caption yang muncul di halaman twitter mereka, efek pesan berantai akan teraplikasi jika berita ataupun informasi yang diunggah dianggap menarik oleh netizen. Ini menjadi tantangan lain tentang bagaimana KPU dalam media sosialnya bisa membuat sebuah Set-Up terhadap sebuah berita yang dirasa penting dan memerlukan penyebaran informasi secara masif, mengedukasi tidak harus selalu lewat tatap muka, namun bisa melalui hal lain, media sosial contohnya, hanya penerapan strategi penyebaran informasi yang tepat dalam menyebarkan informasi.

Cate Thompson - AEC, menyatakan bahwa media sosial sangat cocok dengan suatu evolusi yang sering disebut Darwin. Mungkin kita akan terus berubah sepanjang jalan terkait dengan media sosial. Ide yang disampaikan adalah ide-ide yang sangat bagus, dan jika bisa dikonsolidasikan akan menjadi suatu yang sangat bagus. Ada beberapa ide yang patut dipertimbangkan. Antara lain adalah matamassa. Ini adalah suatu potret bagaimana penggunaan dilakukan dengan positif dan sangat baik. Akan selalu ada cara lain dalam menggunakan sosial media termasuk sosialisasi Pemilu.

Langkah lain yang bisa ditempuh oleh KPU dalam rangka sosialisasi adalah melakukan pendidikan politik, khususnya sebagai penyelenggara dan teknis pelaksanaan di lapangan yang bekerjasama dengan pihak terkait untuk 
bisa masuk kurikulum pendidikan nasional. Pendidikan politik bisa mulai diajarkan mulai sejak dini dengan cara memberikan pengetahuan tentang apa arti demokrasi secara umum dengan membiasakan diri berdiskusi dan memberikan argument dengan baik dalam sebuah diskusi.

Pendidikan politik bagi generasi muda sejak dini amatlah vital dalam mendukung perbaikan sistem politik di Indonesia. Pengetahuan sejak dini terhadap komponen-komponen kenegaraan, arti nasionalisme, hak dan kewajiban, sistem pemerintahan, Pemilu, dan segala seluk-beluk politik akan melahirkan orang-orang yang berkapasitas dan memiliki arah dalam perbaikan bangsa dan negara. (Arnaldinasrum, 2010).

Prewitt \& Dawson (1977: 140-141) menyatakan ada tipe pengajaran politik yaitu pendidikan kwarganegaraan (civic education) dan indoktrinasi politik. James Colleman, membedakan antara keduatipeitu,bahwapendidikankwarganegaraan atau latihan kewarganegaraan (civic training) merupakan bagian dari pendidikan politik yang menekankan bagaimana seorang warga negara yang baik berpartisipasi dalam kehidupan politik bangsanya. Dan yang dimaksud indoktrinasi politik lebih memperhatikan belajar ideologi politik tertentu yang dimaksudkan untuk merasionalisasi dan menjastifikasi rezim tertentu (Coleman, 1968).

Alfian (1992), dalam bukunya Pemikiran Dan Perubahan politik Indonesia menyatakan bahwa "Pendidikan politik sebagai usaha yang sadar untuk mengubah proses sosialisasi politik masyarakat sehingga mereka memahami dan menghayati betul nilai-nilai yang terkandung dalam suatu sistem politik yang ideal yang hendak dibangun" (p.235). Pendidikan kewarganegaraan berkaitan dengan konsep-konsep yang lebih luas yang mendukung masyarakat demokratis seperti peran masing-masing dan tanggung jawab warga negara, pemerintah, kepentingan politik dan khusus, media massa, dan sektor bisnis dan non -profit, serta pentingnya Pemilu yang periodik dan kompetitif. (Alfian, 1992).

Ini menekankan tidak hanya kesadaran warga negara tetapi partisipasi warga dalam semua aspek masyarakat demokratis. Pendidikan kewarganegaraan merupakan proses yang berkelanjutan, tidak terikat dengan siklus Pemilu dan dapat dilakukan melalui sistem sekolah dan
Universitas. Dalam konteks Indonesia, pendidikan kewarganegaraan juga merupakan bagian dari kurikulum sekolah terutama di sekolah sejak Sekolah Dasar hingga Universitas. Dalam lampiran Permendiknas No 22 tahun 2006 di kemukakan bahwa "Mata pelajaran Pendidikan Kewarganegaraan merupakan mata Pelajaran yang memfokuskan pada pembentukkan warga negara yang memahami dan mampu melaksanakan hak-hak dan kewajibannya untuk menjadi warga negara Indonesia yang cerdas, terampil, dan berkarekter yang diamanatkan oleh Pancasila dan UUD 1945"

Kemudian, pengenalan tentang tata cara pemungutan suara seperti yang dilakukan di TPS juga sudah mulai diajarkan sejak dini, sehingga apa yang nantinya akan dilakukan di TPS sudah menjadi kebudayaan ketika para generasi muda ini tumbuh nantinya. Hal ini akan memberikan benefit bagi penyelenggara, karena masalah sosialisasi tentang tata cara pemungutan suara sudah mengakar dan hal ini bisa diterapkan dalam suatu kelas ataupun lingkup yang lebih besar ingin mencari ketua kelas ataupun ketua OSIS.

Hal ini sebenarnya sudah dilakukan KPU di daerah dengan adanya PEMILOS (Pemilihan Ketua Osis) bahkan hal ini sudah dilakukan sejak tahun 2011 (SUARA KPU, KPU Semarang Laksanakan Pemilos Pertama di Indonesia, September 2011). Pemilos, adalah sarana pelaksanaan demokrasi dilingkungan sekolah untuk memilih Ketua OSIS yang diselenggarakan secara langsung, umum, bebas, rahasia, jujur, dan adil. Namun sayangnya hal ini hanya menjadi kreasi KPU di level bawah yang memiliki tingkat antusiasme dan pendidikan yang berbeda-beda, dan bukan menjadi kebijakan Nasional.

Elemen pendidikan politik ini ibarat sebuah koefisien dalam rumus matematika yang dapat mempengaruhi unsur-unsur lainnya, tidak hanya partispasi politik tetapi juga kualitas dari para wakil rakyat dari dan di dalam tubuh partai politik itu sendiri. Indonesia mungkin adalah negara yang memiliki kegiatan ke-Pemiluan paling kompleks di dunia. Dengan empat juta petugas di 550.000 tempat pemungutan suara (TPS), yang tersebar di berbagai penjuru sebuah negara yang terdiri atas 17.000 pulau, bertugas mengelola 775 juta surat suara dengan 2.450 desain yang berbeda untuk memfasilitasi 
pemilihan 230.000 kandidat dalam satu Pemilu presiden dan 532 dewan perwakilan di tingkat nasional dan daerah. (www.rumahpemilu.org, 2014).

Hal ini menyebabkan publik begitu berjarak dengan kegiatan Pemilu dan menganggapnya sebagai even lima tahunan semata. Hal ini juga adalah tantangan besar bagi pemerintah untuk memberikan pendidikan, sosialisasi dan informasi kepada segenap rakyat Indonesia karena tanpa adanya pendidikan pemilih yang baik sulit bagi masyarakat untuk mengetahui apa urgensi memilih, Bagaimana cara menjadi pemilih cerdas dan hal-hal apa saja yang harus diperhatikan dalam memilih seorang kandidat.

Inovasi sosalisasi tentang Pemilu sangat penting dilakukan agar penyelenggaraan Pemilu dari waktu ke waktu semakin berkualitas. Bagaimanapun juga Pemilu telah menjadi harga mati sebagai mekanisme untuk menghasilkan pemerintahan yang demokratis. Sosialisasi politik yang berhasil dengan baik dengan sendirinya akan mendukung Pemilu menjadi lebih baik. Pengalaman Pemilu-Pemilu sebelumnya ataupun Pemilihan Kepala Daerah di berbagai daerah di Indonesia harus menjadi pelajaran tentang bagaimana harus menyelenggarkan Pemilu dengan lebih baik.

\section{SIMPULAN}

Sosialisasi politik dalam Pemilu merupakan hal yang sangat penting untuk menunjang keberhasilan Pemilu itu sendiri, khususnya untuk menekan angka golput dan memberikan semacam penanaman nilai atau norma sosial sehingga bisa meminimalisir black campaign. Proses sosialisasi politik Pemilu oleh KPU yang selama ini dilakukan dinilai efektif sebab mampu menekan angka golput disaat muncul kekhawatiran akan semakin rendahnya partisipasi politik masyarakat namun sayangnya KPU belum menyentuh sosialisasi politik dalam rangka kepanjangan tangan KPU sebagai penyelenggara Pemilu hingga level penyelenggara ad-hoc.Efektifnya proses sosialisasi politik yang dilakukan KPU diharapkan tidak berhenti hanya pada periode Pemilu saja, masih banyak pekerjaan rumah yang harus diselesaikan oleh KPU sebab masih ada permasalahan lain yang juga tidak kalah penting dalam proses sosialisasi politik.
Inovasi dalam sosialisasi juga harus dilakukan KPU untuk menciptakan budaya baru dalam berdemokrasi. Termasuk didalamnya juga menggunakan media baru agar sosialisasi lebih hemat biaya dan lebih tepat sasaran. Kemudian KPU dalam bersosialisasi sebaiknya melakukan inovasi dengan bekerjasama dengan pihak-pihak terkait untuk memasukkan pendidikan politik termasuk didalamnya tugas dan kewajiban menjadi penyelenggara Pemilu dalam mata kuliah Pendidikan Kewarganegaraan, hal ini karena Pendidikan Kewarganegaraan berkaitan dengan konsep-konsep yang lebih luas yang mendukung masyarakat demokratis seperti peran masingmasing dan tanggung jawab warga negara, pemerintah, kepentingan politik dan khusus, media massa, dan sektor bisnis dan non -profit, serta pentingnya Pemilu yang periodik dan kompetitif.

Tidak lupa, KPU diharapkan bisa menciptakan budaya baru pada generasi muda dalam rangka memilih seorang pemimpin, baik itu di level sekolah maupun level berjenjang diatasnya maupun dibawahnya. Hal ini tentu saja akan mempermudah KPU dalam rangka sosialisasi tata cara pencoblosan dalam pemungutan suara, dan bukan hanya dilakukan mendekati Pemilu saja.

\section{DAFTAR PUSTAKA}

Alfian. 1992. Pemikiran Dan Perubahan Politik Indonesia. Jakarta: Gramedia Pustaka Utama.

Annan, Koffi A. 2012. Deepening Democracy: A Strategy for Improving the Integrity of Elections Worldwide. Geneva: Koffi Annan Foundation; International IDEA.

Arnaldinasrum. 2010. Desember 19. Accessed 04 10, 2016. http://www.kompasiana. com/arnaldinasrum/pendidikan-politiksejak-dini-bagi-anak-bangsa_55005673 a33311e5725108e2.

Asshiddiqie, Jimly. 2005. Hukum Tata Negara Dan Pilar-Pilar Demokrasi,Serpihan Pemikiran Hukum, Media dan HAM,. Jakarta: Konpress.

Budiardjo, Miriam. 2008. Dasar-Dasar Ilmu Politik. Jakarta: Gramedia Pustaka Utama. 
Coleman, James S. 1968. Education and Political Development. New Jersey: Princeton University Press.

Damsar. 2011. Pengantar Sosiologi Politik. Lampung: Kencana Prenada.

Davis, K., and J.W. Newstrom. 1996. Perilaku dalam Organisasi. Edisi ketujuh. Jakarta: Erlangga.

Dawson, Richard E., Kenneth Prewitt, and Karen S. Dawson. 1977. Political Socialitazion: An Analytic Study - second edition. Brown Little.

ERI. 2015. Evaluasi Pemilihan Presiden/ Wakil Presiden 2014. Jakarta: ERI.

Hyman, Herbert. 1959. Political Socialization. A Study in the Psychology of Political Behavior by Herbert H. Hyman. New York: Free Press.

Kantaprawira, Rusadi. 2004. Sistem Politik Indonesia, Suatu Model Pengantar. Bandung: Sinar Baru Algensindo.

Kotarumalos, Amir, interview by Republika. 2014. Jelang Pilpres, Pelanggaran Pemilu Harus Diantisipasi (Mei 15). Accessed 4 23, 2016. http://www.republika.co.id/ berita/pemilu/berita-pemilu/14/05/15/ n5ljra-jelang-pilpres-pelanggaranpemilu-arus-bawah-harus-diantisipasi.

Lowden, Kevin, Stuart Hall, Dr Dely Elliot, and Jon Lewin. 2011. Employers' Perceptions of The Employability Skills of New Graduates. London: Edge Foundation.

Marwanto. 2015. http://www.rumahpemilu. org/eng/read/8790/Regenerasi-BadanAd-Hoc-Pemilu-oleh-Marwanto.html. April 27. Accessed April 10, 2016. http://www.rumahpemilu.org/eng/ $\mathrm{read} / 8790 /$ Regenerasi-Badan-AdHoc-Pemilu-oleh-Marwanto.html.

Nagano, Hitoshi. 2012. "Trends in human Resource Recruitment in Companies. The Situation After The Financial Crises of 2008." The Japanese Journal of Labour Studies 54 21-28.

Orfalea, Paul. 2007. Copy This!: Lessons from a Hyperactive Dyslexic who Turned a Bright Idea Into One of America's Best Companies. Workman Publishing
Company.

2012. "Peraturan Menteri Pendayagunaan AparaturNegara dan Reformasi Birokrasi Republik Indonesia nomor 83 tahun 2012 tentang Pedoman Pemanfaatan Media Sosial Instansi Pemerintah."

Perludem. 2014. Mendorong Partisipasi Masyarakat Dalam Pemilu 2014. Jakarta: Perludem.

Putri, Maslekah Pratama. 2015. "Peran Komisi Pemilihan Umum Dalam Sosialisasi Pemilu sebagai upaya Untuk Meningkatkan Partisipasi Politik Masyarakat Pada Pemilu Presiden 2014 di Kalimantan Timur." ejournal.ilkom.fisipunmul.org 30-43.

Sheedy, Caroline S. 2011. "Social Media for Social Change A Case Study of Social Media Use in the 2011 Egyptian Revolution."

Stanley, Andy. 2011. Enemies of the Heart: Breaking Free from the Four Emotions That Control You. Colorado: Multnomah Springs.

2011. "Suara KPU." Semarang Gelar Pemilos Pertama di Indonesia. Jakarta.

Surbakti, Ramlan, and Didik Supriyanto. 2013. Partisipasi Warga Masyarakat Dalam Proses Penyelenggaran Pemilihan Umum. Jakarta: Kemitraan bagi Pembaruan Tata Pemerintahan.

Tia Subekti. 2014. Partisipasi Politik Masyarakat Dalam Pemilihan Umum Studi Turn of Voter dalam Pemilihan Umum Kepala Daerah Kabupaten Magetan Tahun 2013. Malang.

2002. "Undang Undang No. 18 tahun 2002 Sistem Nasional Penelitian, Pengembangan, Dan Penerapan Ilmu Pengetahuan dan Teknologi."

www.rumahpemilu.org. 2014. http://www. rumahpemilu.org/in/read/3366/BriefOverview-of-the-2014-Elections-inIndonesia.html

http://www.rumahpemilu.org/in/read/3366/ Brief-Overview-of-the-2014Elections-in-Indonesia.html. 